Gesnerus 55 (1998) 58-69

\title{
Water, Air and Light - Arnold Rikli (1823-1906)
}

Zvonka Zupanič-Slavec

Cirila Toplak

\section{Summary}

This article is a reminder of a famous Swiss healer, Arnold Rikli, who is also considered to be one of the pioneers of the modern health tourism in Slovenia. Rikli moved to the Alpine region of Lake Bled in 1855 to build a health resort after having established his own natural healing method based on the effects of light, air and water on the human body. His resort was visited by rich patients who were treated for numerous diseases under special, "revolutionary" conditions. The inhabitants of Bled and the official medicine strongly opposed Rikli's activities, also because of Rikli's particular character, but some of his practices are still relevant today.

\section{The health resort Bled}

"On the lake, nearby the Triglav, a boat is floating hither and thither."1

Bled (Veldes) is a small town by the lake of the same name, situated in the north-western part of Slovenia and surrounded by the Julian Alps and the mountains of Karavanke. The centre of the Bled valley is an Alpine lake at $475 \mathrm{~m}$ of altitude, with a romantic island in the middle. The air there is clean, refreshing and without dust. Because of the proximity of the Adriatic sea, Bled has a mild Alpine climate - winters are not harsh, summers are

1 An extract from an old Slovenian folk song, describing Bled and its surroundings. Triglav is the highest Slovenian mountain.

Cirila Toplak, Ph. D., Zvonka Zupanič-Slavec, M. D., M. Sc., Medical Faculty, Institute for the History of Medicine, Zaloška 7a, 1000 Ljubljana, Slovenia 
quite warm. There are no sudden changes of temperature, winds and rain are rare $^{2}$.

Although the spa tourism began to develop there only in the middle of the 19th century, Bled had been known for its thermal fountains for at least two centuries before the famous "nature doctor" Arnold Rikli settled there in 1854 to make the resort known all over Europe.

The historian J. V. Valvasor reported in his "Glory of the Duchy of Carniola" in 1689 about mineral water of Bled and even about simple thermal baths that were visited by noble patients ${ }^{3}$. Balthasar Hacquet de la Motte was the first scientist to analyse the thermal sources of Bled in 1779. In 1784 his chemical analysis of the thermal water was published in "Oryctographia Carniolica" 4 .

Hacquet de la Motte stated on the basis of his analysis:

"... As the warmth and the mineral contents of this water are not rich, its effects must be minor; because if the warmth should be the least effective, the water should have 27 to 29 degrees Réaumur at minimum or 98 to 100 degrees Fahrenheit; if its effectiveness was to come out of minerals, it should contain a far greater amount of them than it actually does. Undoubtedly it had to be better some time ago than it is now because there are only few who choose to improve their health by it; and who knows if the loss that the water had suffered out of impoverishment of its qualities is the only reason why it was completely abandoned as in this country many sources are of better quality."

Two Slovenian scientists did the second analysis in $1821^{6}$ and discovered that the water contained high levels of magnesium carbonate and calcium. It is strange that they did not mention the iron carbonate although the water contained important amounts of this substance as it was later proved. The analyses of the Vienna University did not foretell a great future to the thermal fountain in Bled. Dr. Ignaz Laschan analysed the water once again in 1822 on the order of local authorities. The analysis showed that the water in the warm fountain of "Louisenbad" contained iron carbonate and had a stable temperature of 23 degrees C. In 1874 Kletzinsky found that the water contained, beside the already mentioned carbonates, also great amounts of iron, even greater than the famous "iron fountains" in Switzerland and Germany?.

2 Borisov, P. Riklijev delež v razvoju Bleda. (Rikli's contribution to the development of Bled) Turist Vestn 6/1967, Turistična zveza Slovenije, Ljubljana, 1967:261-8.

3 Borisov, P. Stodvajset let od ustanovitve naravnega zdravilnega zavoda na Bledu. (One hundred and twenty years from the foundation of the natural healing institution in Bled) Zbornik za zgodovino naravoslovja in tehnike. Slovenska matica, Ljubljana, 1975: 160-73.

4 Leskovar, R. Z B. Hacquetom skozi slovenska zdravilišča pred 180 leti. (With B. Hacquet through Slovenian spas one hundred and eighty years ago) Zdrav Vestn 1963; 32: 305-13.

5 Ibid.: 306. Translated by Cirila Toplak.

6 Borisov, P. Stodvajset let ....(n. 3 above): 163 .

7 Borisov, P. Riklijev delež v razvoju ...(n. 2 above): 262 . 


\section{Arnold Rikli}

"Water is beneficent of course, air even more and light is the most beneficent of all."

Arnold Rikli ${ }^{8}$

Arnold Rikli was born on February 13, 1823 in Wangen in Switzerland. He was a son of Friedrich Rikli, a rich factory owner. Throughout his youth he enjoyed the beauties of the Swiss countryside with clean water in the nearby Aar, fresh mountain air and warm sun. After having successfully terminated his studies (he was excelling in mathematics and chemistry), he started working in his father's factory, although not completely out of his free will. In his spare time he studied chemistry and performed experiments in his father's laboratory. When experimenting with the effects of air and light on plants he realised that similar effects should also be detected when the human body was concerned.

When young Arnold travelled throughout European countries like France, Belgium, Germany, Austria and Italy, in order to become familiar with the organisation of factories similar to his father's, he stopped for one winter near Triest. There he first got in touch with hydrotherapy as he came to read Dr. Carl Munde's Hydrotherapy 9 . Under the influence of that reading he dropped work in the factory and started to heal himself with different cures described in the book. A healthy man, he subsequently lost quite some weight and generally weakened.

After his return to Switzerland Rikli fell seriously ill. The doctors already found his dysentery hopeless, but when his condition became severe indeed, he started healing himself according to hydropathic rules, and he recovered completely in three days only. His doctors were stunned. In 1846 Rikli moved to Seebach in Upper Carinthia in order to found a factory similar to his father's. His business went well and he was soon employing 300 workers. His workers were, naturally, ill from time to time, and Rikli was far more interested in healing them than in running the factory. He soon became such a famous healer that patients from nearby villages were also seeing him. As to the factory, it was managed by his brothers most of the time.

In May 1852 Rikli fell very ill again, this time he suffered from pleuritis. He did not even call a doctor anymore but assumed the treatments autonomously. His nurses were given hydropathic instructions which once again

8 Benedik, B. Bled in Arnold Rikli. (Bled and Arnold Rikli) Turistično društvo Bled, Bled, 1980: 1.

9 Munde, C. Hydrotherapie od. d. Kunst d. Krankheiten des menschl. Körpers, ohne Hülfe von Arzneien, durch Diät, Wasser, Schwitzen, Lust und Bewegung zu Heilen und durch eine vernünft. Lebensweise zu verhüten. Ein Handbuch f. nicht-Ärtzte. Leipzig, 1841. 
proved to be successful. In order to recover fully, he travelled to nearby Bled for rest. He appreciated the freshness of the air and the clean water in the lake of Bled so much that he returned to Seebach only to pass his share of the factory to his brothers and move his possessions to Bled for good. He decided to found a natural health resort in Bled, called "Natural healing institution" and to run it as an "atmospheric" doctor having no official medical education.

Thus, in 1855 Rikli was in Bled, ready to start a revolution in the medical treatments of numerous diseases with a new, hydropathic approach. Many obstacles had to be overcome before his resort became successful and famous, particularly the mistrust of the inhabitants of Bled and the despise of the medical milieu. The local inhabitants feared anything unknown and new; the physicians were afraid of the competition. Slowly, Rikli made his way. Several times he was called to Ljubljana where he performed some successful treatments. In 1859 he moved to Triest and for the following 33 years he shared his time between Triest and Bled. Later on, he also founded medical offices in Merano and Florence.

Rikli's introduction of vegetarian diet as well as sun, air and light baths seemed quite unacceptable in the beginning. He was often ridiculed in the newspapers and accused by doctors of being a charlatan. In 33 years he appeared seven times in court for such accusations, but he was always honourably released. He also produced several articles in order to describe his theories which, however, had no scientific medical foundations ${ }^{10}$.

Rikli directed his institution until his death in 1906. After 1906 his son, Oscar Rikli, became the owner ${ }^{11}$. After World War I a nobleman Ivan Kenda and his wife took over the resort but their conception of health tourism was quite conventional compared to Rikli's.

\section{Daily therapy of Rikli's patients}

In 1859, Rikli built a simple wooden building in the centre of Bled - "in the Swiss manner" - with a large bathing hall on the ground floor and bedrooms

10 Karlin, M. Ob stoletnici Riklijevega zdravilišča na Bledu. (One hundred years of Rikli's spa in Bled) Priroda, človek in zdravja. DZS, Ljubljana, 1955: 117-123.

11 Borisov, P. Riklijev delež v razvoju ...(n. 2 above): 268. It is interesting that Karlin (Karlin, M. Ob stoletnici ...(n. 10 above): 120) states that Dr. Richard Eder took over the resort after Rikli's death. Most probably, Oscar Rikli became the owner in 1906 when Dr. Eder managed the actual medical work only. 
on the first floor. The side of the building which was facing the lake was arranged as a covered hut for air baths and a gallery for sun baths. In 1899, Rikli had to build a bigger building on the same spot. For himself, he later also built a villa, called "Mežaklja".

Characteristic for Rikli's healing were wooden huts, where his patients slept. The huts had narrow roofs, all furniture that was in them were a couple of beds and some modest accessories. The huts had curtains instead of doors that were closed only at night. As all the huts were oriented towards the lake the visitors could constantly enjoy fresh air and the beautiful view of the lake.

Walks were also an important part of the therapy, so Rikli chose several destinations around Bled and divided the walkers by sex and by degree of difficulty of the prescribed destinations. He named all those destinations with Swiss names ("Riklikulm", "Arnoldshöhe", "Rolandshain", etc.) ${ }^{12}$. On certain points of those destinations Rikli arranged playgrounds for bowling and skittle-playing. In some places male patients could sunbath completely naked.

For the trips men were dressed only in white cotton skirts or shorts and women wore special shirts. Their heads were protected from the sun by simple straw hats, if they wore any at all. As they had to walk through dewy grass and in order to achieve a better blood circulation the patients wore open sandals. Rikli did not appreciate modern, sometimes very uncomfortable clothes - they were even forbidden in his institution. Modest, uniform clothes also had a positive psychological effect on his patients which for the major part were representatives of the "rich and famous". The treatment was combined with simple vegetarian food. Patients were given meat at special occasions only, and they had to pay for it separately. Smoking and drinking alcohol were strictly forbidden.

Usually, the patients took a walk right after waking up which was, particularly for some lazy and spoiled patients, very early - at five or six o'clock. The walks could take from half an hour for the weakest patients to four hours for the strongest men. They took breakfast along with them and ate it on the way sometime between 7 and 9 a.m. The breakfast included black bread or home-made bread, half a litre of milk and a little honey. Instead of milk the patients could also have a coffee substitute and sugar. Certain patients had

12 Rikli was vividly and often reproached to give exclusively Swiss names to his buildings and destinations (see Benedik, B. Bled in Arnold Rikli, n. 8 above) but that seems to be only partially justified if we consider the name of his own house. Mežaklja is a high plain in the Julian Alps. 
a different breakfast, composed of chocolate, cocoa, tea, butter or fruit juice, if the doctor prescribed so, but they had to pay for it separately ${ }^{13}$.

After having taken a walk, the patients had to rest or bathe in the Lake Bled or in Rikli's baths. The water there was actually heated lake water because Rikli did not care for the nearby lukewarm thermal springs. Two cold sources for bathing were also used where the water temperature was less than 10 degrees $\mathrm{C}$. The order of activities was important, because the body was heated up by walking and sunbathing and had to be cooled down by a bath and then rest. Afterwards, it all started over again. Men and women separately took warm and steam baths and had at their disposition several showers (a free falling one, a horizontal shower, a vertical shower, a rainy shower, a spiky shower, etc.). After bathing, sunbaths, and massage they had a modest lunch composed of bread and milk or soup.

After a vegetarian dinner some social activities were organised for the patients as well, like boating on the lake, etc. Usually, they went to bed already around 9 p.m.

The patients had to follow the instructions of the therapy very strictly. Whoever was not "serious" (by certain data about $10 \%$ of the guests) had to leave the institution ${ }^{14}$. It has to be admitted that Rikli's patients had problems with the rules, above all those regarding food. When they could not stand the firm diet anymore, they left for the nearby inns for stew and beer. If their "atmospheric doctor" caught them, he did not spare harsh words and sometimes even threw them out of his institution. Rikli published the rules of the "Mallnerbrunn healing institution" in 1886, with prices for special services included ${ }^{15}$.

Rikli also directed the medical service himself. After a certain period, when he could no longer manage the growing number of patients, he hired doctor Richard Eder, a hydropath from Vienna, to assist him.

The price of the therapy was high, and as it lasted for a month it was primarily accessible to rich patients. It soon became a fashion that drew thousands of people to Bled every year. The flow of tourists and patients was

13 Janša-Zorn O. Zgodovina blejskega turizma od začetkov do 1941. (History of tourism in Bled from its beginnings until 1941) Kronika časopis za slovensko krajevno zgodovino, letnik 32. Zgodovinsko društvo za Slovenijo, sekcija za krajevno zgodovino, Ljubljana, 1984: 182-196. The "doctor" was, of course, Rikli himself. His way of health tourism was a highly profitable business but there are numerous indications like the rejection of many patients, for example, that Rikli did not do it for money.

14 Barešov, P. Betetto. Bled in Arnold Rikli v zgodovini helioterapije. (Bled and Arnold Rikli in the history of heliotherapy) Zdrav Vestn 57/6, 1988: 271-272.

15 Rikli,A. Cur und Hausordnung der Naturheilanstalt Mallnerbrun am Veldeser See, Oberkrein, 1886. 
intensified after the railway connection had been built between Ljubljana and Treviso via Bled in 1868. In 1881, 1094 people visited Bled, and in 1905 their number more than doubled to 2640. Rikli's fans became so numerous that Rikli founded "a club of the virtuous" in 1869 which was actually the club of the "riklies" so to speak, of people who took Rikli's rules so seriously that they became a way of life to them ${ }^{16}$.

\section{Arnold Rikli and his work in the local context}

The health tourism was undoubtedly most beneficent to the local population in Bled. It attracted rich guests from an aristocratic sphere, enabled local people to get employed in various activities and opened Slovenia to the larger European space. The culture of healthy nutrition and care for the general health developed.The surroundings of the lake were enriched architecturally by numerous prominent objects.

Rikli's relations with the inhabitants of Bled, the local authorities and the Health resorts' commission were quite particular. The local people hardly remember him, but the general opinion is that he was a rather weird man who did not seek contacts with the locals and never wanted to learn the Slovenian language. He appreciated neither the capability nor the ingenuity of the inhabitants of Bled. Thus, he stated in one of his publications that the local people lacked the intelligence to draw the foreigners' attention to the beauties of Bled and its environment ${ }^{17}$. A foreigner, in the person of Rikli, had to come to reveal Bled to other foreigners. Professor F. X. Šalda, a literary theoretician from Charles University in Prague, left an illustrative testimony of Rikli's influence on Bled: "The 'riklies' walk around in sandals and without hats; they seem to be puppets filled with electricity. Everything looks like an operetta and one hardly believes that anyone is really ill here." 18

The locals observed with growing mistrust Rikli's patients who were, relatively to the rules of fashion in those days, scantily dressed. Sunbaths of naked male patients in the vicinity of Bled represented a scandal to the rather puritan majority of the inhabitants. No wonder that Rikli was often mentioned at the sessions of the community council from which he received numerous warnings.

16 Borisov, P. Stodvajset let ... (n. 3 above): 172 .

17 Benedik, B. Bled in Arnold Rikli (n. 8 above): 9.

18 Janša-Zorn O. Zgodovina blejskega turizma ... (n. 13 above): 185. 
Rikli did not collaborate with other hotel and inn owners in Bled. He kept reminding his guests of the necessity of precise reservations in his institution and refused unexpected arrivals because he "had no intention of helping other hotels in Bled. They are to take care of their guests on their own."19

Nevertheless, Rikli had, in spite of his attitude and the consequential mistrust, some imitators in Bled itself. The people in Bled did possess commercial talent. "If Rikli manages this kind of tourism well, why would not we try also", thought one of the local families, the Vovk, and built a similar resort nearby their house. Although the Vovk's institution also had open huts, pools and walks, the regime of nutrition was not as strict as at Rikli's house. Thus, several patients who could not comply with Rikli's regime decided to move to Vovk's pension which represented more of a hotel than of a health resort. Rikli even sued the Vovk because the latter performed his therapy without any medical control. It should also be mentioned that in 1902 exactly the same health resort was built in Switzerland, in the village of Degersheim under the Säntis, by one of Rikli's grateful patients.

Not all the people in Bled recognised the importance of Rikli's contribution to the development of tourism in Bled. Many argued that there had been comfortable hotels at Bled already before Rikli's arrival, and quite some guests, Slovenes and foreigners, had regularly visited the region. The promoters from Bled supposedly travelled to important European cities and attracted tourists.

If Rikli did not start the tourism at Bled, he definitely started the organised tourism, and this is his most important merit for that part of Slovenia. Rikli showed the inhabitants of Bled that it is possible to earn money with tourism as well as with commerce or other activities.

His followers could not develop his work further on because of World War I. The remains of his health resort have been proclaimed a cultural monument in $1992^{20}$. Some years ago the local tourist agency Kompas decided, together with local authorities, to tear down the villa "Rikli", a part of the resort complex. This plan was obstructed by the inhabitants of Bled and the Institution for Protection of Natural and Cultural Heritage in nearby Kranj. Still, the building was in such bad shape that it was painful to look at. In 1993 a new owner took over who promised to renovate it without any commercial ambitions.

19 Benedik, B. Bled in Arnold Rikli (n. 8 above): 9.

20 Benedik, B. Bled in Arnold Rikli (n. 8 above): 1. 


\section{Arnold Rikli and his work in a broader medical context}

If we want to understand the reactions of the official medicine to Rikli's therapeutic approach, we have to put it into a proper context of the history of similar therapies.

According to material and written proofs, hydrology and therapeutic climatology were already developed by the civilisations of the Antiquity and this tradition goes even further back to biblical times ${ }^{21}$.

Modern bath techniques were introduced in Europe mostly from abroad. The rational medical development of hygiene is posterior to numerous fashionable therapeutic fantasies related to the use of water for curative purposes, with the exception of thermalism proper.

At the beginning of the 19th century natural schools were founded in German-speaking countries as an alternative to mainstream medicine which was, in terms of development, stagnant at the time. These "schools" or "methods" were well received by the people because of their simplicity and apparent logical bases. Their most important weakness was that they were exclusively empirical; later-on thorough studies and comparative clinical research discredited many of them. The favourable reception was related to the philosophical fashion of romanticism and the general state of mind in Germany, Austria-Hungary, and Switzerland, which resulted in a decelerated scientific progress. This is why the French and English became the leaders in terms of medical discoveries and improvements in that period. This may also be the reason why the doctors from those countries were suspicious of natural medicine in general.

The romantic medicine of the 19th century which, with its cult of Nature, especially in Germany, did a lot of damage to the progress of scientific medicine, contributed on the other hand to the re-popularisation of simple therapies, among which was hydrotherapy. Its most important figure of the period was undoubtedly the famous priest Sebastian Kneipp (1821-1897). Having suffered from tuberculosis in his youth he was saved by special hydrotreatments which are known today as "Kneippkur" and which replace the regular hydroclimatism in many German, Austrian and Swiss spas. The most important measures of the "Kneippkur" are on the one hand bathing in hot and cold water alternatively, and on the other, partial bathing of certain body parts. The similarities with Rikli's hydrotherapy are evident ${ }^{22}$.

21 Haumont, C. Tout savoir sur l'eau. Faure, Paris, 1989: 15-60 and Véraldi, G. Guérir par l'eau. France Loisirs, Paris, 1977: 39-56.

22 Kneipp, like Rikli, recommended walking in dew or cold water every day. The cold treatments are not to be applied to the cold body but to parts previously warmed; one should not 
Kneipp undoubtedly found efficient means to reinforce the immune system and physical fitness which tends to weaken in the urban environment. However, his pretensions to heal every known disease by purifying the blood and other body liquids ranged Kneipp cures among potentially questionable if not dangerous medical treatments. Rikli's therapy was also known to heal numerous diseases. Nevertheless, Rikli never pretended to possess the universal treatment for all illnesses. On the basis of examination of detailed anamneses that he always required from his patients, he even refused to treat many of them.

Rikli's "natural healing method" was based on the persuasion that an illness related to any organ led to the weakening of the entire organism. The treatment, acting through the arterial and nervous system, should primarily increase the general immune capacity of the body. Secondarily, the treatment was believed to also act in a retroactive way affecting any diseased organ and resulting in a regeneration of the entire organism. The illnesses that could supposedly be healed in this way were the following: anaemia, migraine, neurosis, hysteria, menstrual dysfunction, womb infections, haemorrhoids, paralysis, dermatoses, and sexual dysfunctions of different sorts ${ }^{23}$.

In his work Rikli relied mostly on two of his contemporaries: Vinzenz Priessnitz (1790-1851) and Sebastian Kneipp. The official medicine strongly opposed their activities and finished by partially recognising them, for example Priessnitz' compresses in dermatology which are still in use ${ }^{24}$.

Rikli fervently opposed the medical opinion of the inefficiency of temperature changes. He was constantly attacking doctors "because of the healing with artificial drugs" as well. His book Die Fieberkrankheiten ${ }^{25}$ was even officially forbidden in Austria in 1900. Rikli was also courageous in his opinion on the positive effect of sun rays. The doctors at the time were worried about the damage the sun could do to the skin, and they recommended to hide it as well as possible under the attire. Only decades after Rikli, tanned skin became a universal fashion and even a social attribute ${ }^{26}$.

"kneipp" himself right after a meal and should always dry naturally, etc. which are all very meaningful instructions as seen from the contemporary perspective although at the period they had no scientific foundations.

23 Barešov, P. Betetto. Bled in Arnold Rikli ... (n. 14 above): 272.

24 Ibid.

25 Ibid.

26 Here Rikli was both right and wrong. It is common knowledge today that sun is beneficent to the human body because of the production of vitamin D, but on the other hand overexposure to the sun's UV rays can cause skin cancer. 


\section{Modern "riklies"}

It is significant that nowadays medicine slowly starts to change the perspective of patient treatment. The patient has gradually ceased to be just a sum of diseased organs and is once again a human being who has to be treated as a whole, including his thoughts, feelings, emotions.

Rikli's approach to patient treatment more than a century ago was genuinely advanced. His natural healing method was not borne out of a desire to earn money by misleading trustful people as many charlatans have done, but out of a deep mistrust with classical medicine which had not succeeded in healing many diseases. His method was empirical, but not in a way that he would by pure chance once discover a beneficent treatment and then generalise it to cure all cases of the same illness or even most of the existing illnesses. Rikli was from his youth convinced of the effects of light, air and water, and his method had something of a life philosophy. He truly believed in his method. This is why he relied on such a strict regime in his institution and preferred letting some patients move to less strictly managed resorts rather than taking the responsibility for their health.

It is important to acknowledge that the Slovenian medicine in the 19th century followed closely the Austrian and German medicine regarding the general standards of health care and efforts for taking better medical care of the population. Among the principal achievements early introduction of vaccinations and important improvement of hygienic standards are to be acknowledged. But on the other hand, Slovenes were strongly influenced by the Catholic church and thus felt very suspicious of Rikli's ideas of behaving, eating and clothing. Although the rich people made such a fashion out of his therapy, it is highly probable that they also took it only as a fashion, with the exception of some "riklies".

When examining the newest trends in public opinion on therapeutic approaches, one could notice that nowadays we are massively becoming "riklies" again. The importance of physical activity is being proved by ever new research studies. Doctors are persuaded today that the length of our life depends on the level of daily activation of our body. The awareness of the importance of healthy food is strengthened by numerous medical proofs of many diseases, aterosclerosis for example, resulting from inappropriate nutrition. People are moving back to the country because fresh air becomes precious and appreciated in the smog of universal industrialisation. The highly developed drug industry meets a serious competitor in producers of homeopathic drugs and healing herbs. Health resorts such as Rikli's have become at present elitist health clinics with all up-to-date medical care 
possible that are closed to the public. As to the majority of resorts, they offer various pleasures of totally "democratised" thermal spas. Decades ago, only old and ill went to spend their vacation in spas, whereas today these institutions are used as true regenerators for all generations, offering all possible services (and a lot of entertainment) on the basis of "healthy" principles. The newest trends in tourism on the other hand reflect new health standards within the post-industrial society. The lazy vacation on the sea side with inevitable sunburns as a consequence of the "tan hunt" is more and more replaced by the so-called active vacation in health resorts or in regions with preserved natural environment.

The way of living greatly changed since Rikli's days. Sun rays have become more dangerous than beneficial to health because of the ozone hole. Many waters are too polluted for bathing, and one has to be careful with the industrially grown and treated food products. Now that nature is already endangered, we are turning back to it. Even the apparently unlimited science starts to acknowledge certain limits regarding the protection of our environment. We seem to finally come to the conclusion that we do not own nature - we are just a part of it. Arnold Rikli became aware of that already more than a century ago.

\section{Additional literature:}

Lukman F. K. Arnold Rikli. In: Slovenski biografski leksikon. SAZU, Ljubljana, 1960: 106.

Anonymous. Razvoj turizma na Bledu. (Development of tourism in Bled) Gradivo turističnega društva Bled.

Bohinec, V. Arnold Rikli in njegov Bled. (Arnold Rikli and his Bled) Turist vest 12, 1953.

Borisov, P. Zdravilišč in kopališča na nekdanjem Kranjskem. (Health resorts and spas in former Carniola) Kronika XVI, 1968.

Benedik, B. Arnold Rikli in Bled. (Arnold Rikli and Bled) Za srce, 1994; 3 (3-4): 43-4.

Demšar, J. Patogenetični vpliv sončnih žarkov na kožo. (Pathogenic influence of sun rays on the skin) Planinski vestnik, 1967: 26-28.

Germovnik, L. Curort Veldes. Wien, 1878.

Germovnik, L. Veldes, ein Naturwunderland Krain. Wien, 1908.

Levental, Z. Der «Sonnendoktor» Arnold Rikli (1823-1906). Gesnerus, 1977; 34: 394- 403.

Premuda, L. La presenza a Trieste di Arnold Rikli (1823-1906) «Medico idropatico» di remota inspirazione cornariana. In: Da Fracastoro al Novecento. La Garangola, Padova, 1996: 388-397.

Minarrik, F. Sto let blejskega vrelca. (One hundred years of the Bled's source) Slovenski narod, 1922.

Murnik, R. Na Bledu. (At Bled) Ljubljana, 1923.

Rikli, A. Anruf an die kranke Menschheit an Körper und Geist. 1857.

Rikli, A. Die Grundlagen der Naturheilkunde. 1894.

Rikli, A. Es werde Licht und es wird Licht. 1894.

Rikli, A. Opis sončnega zdravilišča Arnolda Riklija na Bledu. Ljubljana, 1909.

Rikli, A. Prospekt der Naturheilanstalt Mallnerbrun bei Veldes in Oberkrain.

Rikli, A. Rikli's Bette und Teil-Dampfbäder, 1889.

Rikli, A. Wegweiser zu der Umgebung des Kurortes Veldes, 1862.

Veldes am See. Arhiv Turističnega društva Bled. Ljubljana, 1911. 